\title{
Wallenberg syndrome and isolated lateral bulbar infarction: Clinical characteristics and prognosis in a cohort of Mexican patients
}

\author{
José L. Ruiz-Sandoval1,2*, Fernando Barinagarrementeria-Aldatz ${ }^{3}$, Carlos Cantú-Brito ${ }^{4}$, \\ Antonio Arauz-Góngora ${ }^{5}$, Germán López-Valencia ${ }^{1}$, Amado Jiménez-Ruiz ${ }^{4}$, Patricia Laguna-Cruz ${ }^{5}$, \\ Jesús A. Aldana López ${ }^{1}$, Sergio Cerpa-Cruz ${ }^{1}$, and Christian Menchaca-Gutiérrez ${ }^{1}$ \\ ${ }^{1}$ Department of Neurology, Hospital Civil de Guadalajara "Fray Antonio Alcalde", Guadalajara, Jalisco; '2Department of Neurology, Instituto de \\ Neurociencias Traslacionales, Centro Universitario de Ciencias de la Salud, Universidad de Guadalajara, Guadalajara, Jalisco; ${ }^{3}$ Department of \\ Neurology, Hospital Ángeles, Querétaro, Querétaro; "Department of Neurology, Instituto Nacional de Ciencias Médicas y Nutrición "Salvador Zubirán", \\ Mexico City; Ciudad de México; "Clinic for Cerebral Vascular Disease, Instituto Nacional de Neurología y Neurocirugía "Manuel Velasco Suárez", \\ Mexico City; ${ }^{6}$ Rheumatology Service, Hospital Civil de Guadalajara "Fray Antonio Alcalde", Guadalajara, Jalisco, Mexico
}

\begin{abstract}
Background: Wallenberg syndrome (WS) is a classic neurologic disorder secondary to vascular pathology of the vertebrobasilar circulation. Methods: Consecutive patients > 18 years with WS and isolated lateral medullary infarction syndrome were included from two Mexican hospitals. Risk factors, initial signs, symptoms, radiological findings, and acute treatment were evaluated; the prognosis was assessed using the Glasgow Outcome Scale. Results: Twenty-six patients were studied in a 26-year period (1988-2014); 17 patients were men (67\%); and the average age was 45 years (range 19-77). Fourteen patients were under 45 years old (54\%). The most common risk factors were dyslipidemia (41\%) and hypertension (37\%). The main initial symptoms were vertigo-dizziness (89\%) gait ataxia (70\%), and crossed-sensory deficit; and the main signs were crossed-sensitive deficit (93\%), Horner syndrome (85\%), and nystagmus (82\%). In the bivariate analysis, age under 45 years was associated with a vertebral arterial dissection $(p=0.001)$, and age $>45$ with atherothrombotic etiology $(p=0.01)$. About $96 \%$ of patients presented good recovery at an average of 17 months follow-up. Conclusion: Non-atherosclerotic vasculopathy was the main cause of WS-ILBI in young people. The clinical characteristics were similar to those reported in other series with a usually benign prognosis.
\end{abstract}

Key words: Postero-lateral bulbar infarct. Stroke. Vertebral artery dissection. Wallenberg's syndrome.

\section{Síndrome de Wallenberg e infarto bulbar lateral aislado: características clínicas y pronóstico en una cohorte de pacientes mexicanos}

\section{Resumen}

Antecedentes: El síndrome de Wallenberg (SW) es un diagnóstico clásico en neurología, generalmente secundario a patología vascular de la circulación vertebro-basilar. Métodos: Se incluyeron a pacientes mexicanos consecutivos mayores de

Correspondence:

*José L. Ruiz-Sandoval.

E-mail: jorulej-1nj@prodigy.net.mx
Available online: 11-02-2021

Rev Mex Neuroci. 2021;22(1):3-9

www.revmexneurociencia.com 1665-5044/ @ 2020 Academia Mexicana de Neurología A.C. Published by Permanyer. This is an open access article under the CC BY-NC-ND license (http://creativecommons.org/licenses/by-nc-nd/4.0/). 
18 años de edad con síndrome de SW e infarto bulbar lateral aislado (SW-IBLA) en dos hospitales mexicanos. Se evaluaron los factores de riesgo, signos y síntomas iniciales, hallazgos radiológicos, tratamiento agudo y pronóstico mediante el Glasgow Outcome Scale (GOS). Resultados: Se estudiaron 26 pacientes en un periodo de 26 años (1988-2014); Diecisiete pacientes fueron hombres (67\%); el promedio de edad fue de 45 años (rango 19-77). Catorce pacientes fueron menores de 45 años (54\%). Los factores de riesgo más frecuentes fueron dislipidemia (41\%) e hipertensión arterial (37\%). Los principales síntomas al inicio fueron vértigo-mareo (89\%) y ataxia para la marcha (70\%), así como déficit sensorial cruzado (93\%), síndrome de Horner (85\%) y nistagmo (82\%) a la exploración neurológica. En el análisis bivariado, la edad menor a 45 años se asoció a disección arterial vertebral $(p=0.001)$, y la edad $>45$ a etiología aterotrombótica $(p=0.01)$. El $96 \%$ de los pacientes presentaron buena recuperación en un seguimiento promedio de 17 meses. Conclusión: La vasculopatía no ateroesclerosa fue la principal causa de SW-IBLA en jóvenes. Las características clínicas para esta localización fueron similares a lo reportado en otras series con un pronóstico habitualmente benigno.

Palabras clave: Circulación vertebro-basilar. Disección arterial vertebral. Enfermedad vascular cerebral. Ictus. Infarto bulbar. Sindrome de Wallenberg.

\section{Introduction}

Twenty percent of brain infarctions occur in the vertebrobasilar territory, usually affecting the medulla ${ }^{1-3}$. In bulbar infarctions, the lateral or posterolateral topography is mainly compromised, causing a constellation of signs and symptoms encompassed in the Wallenberg syndrome (WS) ${ }^{4-7}$. The WS has been described throughout history from various perspectives. It began with clinical and clinical-pathological descriptions, followed by neurophysiological studies, as well as vascular findings (due to the use of cerebral angiography), culminating in precise clinical-radiological correlates after the advent of sophisticated magnetic resonance imaging (MRI) $)^{8,9}$. The prognosis for WS is usually favorable, and the sequelae, although frequent, are usually mildly disabling with complete remission in most cases $^{9-11}$. We describe the clinical, radiological, and prognostic findings in a cohort of Mexican patients with WS and isolated lateral bulbar infarction (WS-ILMI) in two consecutive hospital records.

\section{Patients and methods}

Consecutive patients older than 18 years with WS confirmed with MRI admitted to the Neurology Department of the Instituto Nacional de Neurología y Neurocirugía "Manuel Velasco Suárez" (Mexico City, Mexico) from 1988 to 1998 were considered, as well as those admitted to the Neurology and Neurosurgery Department of the Hospital Civil de Guadalajara "Fray Antonio Alcalde" (Guadalajara, Jalisco, Mexico) from 1999 to 2014. Acute, ambulatory cases with these same diagnostic criteria attended in the outpatient clinic were also included in both cohorts. Socio-demographic variables, risk factors for stroke, symptoms at the onset of the infarct, and clinical signs on neurological examination, as well as antithrombotic management in the acute phase and secondary prevention strategies, were also analyzed.

Medullary infarctions were classified according to their location as rostral, caudal o rostrocaudal using MRI (FLAIR/DWI in the most recent cohort). Cerebral angiography, extracranial or transcranial Doppler of vertebrobasilar territory as well as magnetic resonance angiography (MRA) of the brain - individually or in combination - were considered to define the site of vascular stenosis or occlusion: vertebral, basilar, or the posteroinferior cerebellar artery (PICA).

The clinical condition at discharge was evaluated according to the Glasgow Prognostic Scale (GOS), where $1=$ death; 2 = persistent vegetative state, without evident cortical activity; $3=$ severe disability, with dependency; 4 = moderate disability in which he is independent but unable to return to his trade; and $5=$ good recovery, returning to previous activities ${ }^{12}$. During outpatient follow-up, the clinical condition and sequelae in the last evaluation were recorded. Likewise, two age groups were considered: a young group ( $<45$ years) and an older group ( $>45$ years). For the registry of the information regarding clinical, radiological, therapeutic, and prognostic data, the same format was used for all patients.

Demographic data are presented as simple relative frequencies. Age is presented and analyzed as median with minimum and maximum. Pearson's $\times 2$ or Fisher's test was used for nominal variables in the univariate analysis, when values with $n>5$, or $n<5$ were distributed in the boxes of the contingency tables, respectively. The T-student test was used to compare normally distributed continuous variables, and the Mann-Whitney U-test was performed when an ordinal or 
non-parametric numerical variable was distributed between two groups (e.g., comparison of medians). The analyses with $p<0.05$ were considered significant. The analyses and " $p$ " value were calculated at two tails. All cases were captured for analysis in the SPSS Statistics Bass 20.0 program (IBM SPSS Inc. Chicago, IL). Ethics Committees were aware of the study and agreed to its development.

\section{Results}

A total of 73 patients with "medullary infarction," "medullary-cerebellar infarction," or "WS" were initially considered. Of these, 36 patients were excluded: ten due to cerebellar involvement, six because they had simultaneously affected multiple structures of the vertebrobasilar territory, and another 13 because they corresponded to medullary infarcts of anteromedial ( 2 cases) or postero, and posterolateral (11 cases) location. Sixteen cases were excluded due to incomplete clinical or radiological information. Twenty-six patients with WS-IBLI were included for the present analysis.

Of the total of 26 patients, 17 (65\%) were men and 9 (35\%) women with an average age of 44 years (range of 19-77 years). There were 14 (54\%) young patients (younger than 45 years). The main risk factors were: dyslipidemia $(42 \%)$, high blood pressure $(38 \%)$, alcoholism $(35 \%)$, and smoking $(27 \%)$. Two patients $(8 \%)$ had a history of ischemic stroke in another territory (Table 1). According to the location of the WS-IBLI, 18 $(69 \%)$ were caudal, five $(19 \%)$ rostral, and three $(12 \%)$ rostrocaudal.

The most frequent symptoms at WS-IBLI presentation were: vertigo or dizziness $(92 \%)$, gait ataxia $(77 \%)$, headache $(73 \%)$, dysphagia $(65 \%)$, and body $(62 \%)$ or facial $(58 \%)$ hypoesthesia (Table 2$)$, with no significant differences regarding sex or age groups. According to location, dysphagia and dysarthria were less frequent in WS-IBLI with caudal location (all with $p<0.05)$. Facial hypoesthesia was more common in infarcts with a caudal location, while facial paralysis was more frequently documented in those with a rostrocaudal location.

At neurological examination, the main signs were ipsilateral or contralateral abnormalities of sensation $(96 \%)$, nystagmus $(81 \%)$, palatal weakness $(81 \%)$, Horner syndrome $(73 \%)$, and gait ataxia (73\%) (Table 2). Gait ataxia was more frequent in young subjects and facial paralysis in rostrocaudal infarcts $(p<0.05)$.

To identify the mechanism of the stroke, several studies were used, including MRA in 18 patients (69\%), transcranial Doppler ultrasound in 9 (35\%), transesophageal echocardiogram in nine $(35 \%)$, and digital subtraction angiography in eight cases (31\%). The vascular abnormalities included: vertebral stenosis in ten cases $(37 \%)$, vertebral artery occlusion in six $(22 \%)$, PICA occlusion in two (7\%), and PICA stenosis in one (4\%) (Tables 1 and 2). These findings did not show a significant association with the age, sex, or location of the IBLI.

The primary etiology of the WS-IBLI corresponded to non-atherosclerotic vascular disease, including arterial dissection in 12 patients (46\%). In eight patients, the cause was classified as atherothrombotic $(31 \%)$, and in four, it was classified ad cardioembolic (15\%). Two of the patients $(8 \%)$ were classified as cryptogenic. Two cases with thrombophilia were included: one patient with systemic erythematosus lupus (with positive antiphospholipid antibodies and factor $\mathrm{V}$ Leiden) deficiency and another with Protein $C$ deficiency.

Of the potentially cardioembolic sources reported, patent foramen ovale was identified in three cases (in one patient associated with an intra-atrial septum aneurysm) (Tables 1 and 2).

The clinical condition at the time of hospital discharge according to the GOS reported: one death (4\%)-associated with sudden respiratory arrest; 16 patients were discharged with minor non-disabling sequelae $(61 \%)$, eight with moderate sequelae $(38 \%)$, and one patient with severe sequelae (dysphagia) (4\%). Regarding antithrombotic treatment in the acute phase and as a subsequent secondary prevention measure: $21(80 \%)$ patients were treated with antiplatelet agents (17 with aspirin, three with clopidogrel, and two with ticlopidine). Five patients (20\%) were anticoagulated (four extracranial dissections and one cardioembolic).

Follow-up was available with an average of 17 months (range 1-72) with a median 16 months in 25 patients, with a GOS of 5 at the time of the last evaluation in 24 patients $(96 \%)$. The one remaining patient continued with severe dysphagia requiring the use of a permanent nasojejunal tube. In our series, no recurrence of stroke was observed at long-term follow-up.

Regarding the etiology, arterial dissection was significantly associated with age younger than 45 years, since it occurred in ten of 12 cases $(p=0.001)$, while atherothrombotic etiology predominated among those older than 45 years in 8 of eight patients $(p=0.001)$. No other significant differences were observed between arterial findings or prognosis concerning age, sex, and location of the infarction (findings not shown in the table). 
Table 1. General characteristics of patients with Wallenberg syndrome and isolated medullary infarction (WS-IBLI) $n=26$

\begin{tabular}{|c|c|c|c|c|c|c|c|c|}
\hline $\mathbf{N}$ & S/A & Risk factors & Etiology & $\begin{array}{l}\text { Topography } \\
\text { (MRI) }\end{array}$ & $\begin{array}{l}\text { Arterial } \\
\text { findings }\end{array}$ & Treatment & $\begin{array}{l}\text { Follow- } \\
\text { up (M) }\end{array}$ & Sequelae (GOS) \\
\hline 1 & $M / 36$ & Alcohol & $\begin{array}{l}\text { Spontaneous } \\
\text { dissection }\end{array}$ & C-L- Right & $\begin{array}{l}\text { A: V4 Right } \\
\text { occlusion. }\end{array}$ & Aspirin & 72 & $\begin{array}{l}\text { Facial pain } \\
(\mathrm{GOS})=4\end{array}$ \\
\hline 2 & $M / 29$ & ---- & $\begin{array}{l}\text { Spontaneous } \\
\text { dissection }\end{array}$ & C-L- Right & $\begin{array}{l}\text { A-MRI: V3 } \\
\text { Right }\end{array}$ & Anticoagulation & 12 & $\begin{array}{l}\text { Facial hypoesthesia } \\
(\mathrm{GOS})=5\end{array}$ \\
\hline 3 & $\mathrm{~F} / 40$ & AH, Dyslip. & $\begin{array}{l}\text { Spontaneous } \\
\text { dissection }\end{array}$ & C-L- Right & $\begin{array}{l}\text { D: V3 Right } \\
\text { stenosis } \\
\text { A ( } 2 \text { month) } \\
\text { normal. }\end{array}$ & Aspirin & 2 & $\begin{array}{l}\text { Horner/Nystagmus } \\
(\mathrm{GOS})=4\end{array}$ \\
\hline 4 & $M / 33$ & $\begin{array}{l}\text { Alcohol, } \\
\text { Dyslip, } \\
\text { Migraine }\end{array}$ & $\begin{array}{l}\text { Spontaneous } \\
\text { dissection }\end{array}$ & C-L- Right & $\begin{array}{l}\text { A: V3-4 Right } \\
\text { stenosis and } \\
\text { ACPI occlusion }\end{array}$ & Aspirin & 22 & No $(G O S)=5$ \\
\hline 5 & $\mathrm{M} / 46$ & $\begin{array}{l}\text { Sm, Alcohol, } \\
\text { PCD }\end{array}$ & Traumatic dissection & C-L- Right & $\begin{array}{l}\text { RM: V3 Right } \\
\text { dissection. }\end{array}$ & Aspirin & 9 & $\begin{array}{l}\text { Facial hypoesthesia } \\
(\mathrm{GOS})=4\end{array}$ \\
\hline 6 & $\mathrm{M} / 40$ & Dyslip. Sm & Traumatic dissection & C-L- Right & $\begin{array}{l}\text { A: V3 Right } \\
\text { occlusion. }\end{array}$ & Anticoagulation & 14 & None $(\mathrm{GOS})=5$ \\
\hline 7 & $M / 33$ & $\mathrm{AH}$ & Traumatic dissection & C-L- Left & $\begin{array}{l}\text { A: V4 Left } \\
\text { stenosis. }\end{array}$ & Aspirin & 5 & None $(\mathrm{GOS})=5$ \\
\hline 8 & $F / 28$ & ---- & $\begin{array}{l}\text { Spontaneous } \\
\text { dissection }\end{array}$ & RC-L- Left & $\begin{array}{l}\text { A: V3-4 Left } \\
\text { occlusion. }\end{array}$ & Aspirin & 24 & None $(\mathrm{GOS})=5$ \\
\hline 9 & $\mathrm{M} / 46$ & $\begin{array}{l}\text { Alcohol, } \\
\text { Dyslip. }\end{array}$ & Traumatic dissection & C-L-I Left & $\begin{array}{l}\text { A: V4 bilateral } \\
\text { stenosis }\end{array}$ & Aspirin & 24 & None $(\mathrm{GOS})=5$ \\
\hline 10 & $\mathrm{M} / 30$ & ---- & Traumatic dissection & R-L- Right & $\begin{array}{l}\text { A: V3 Right } \\
\text { occlusion. }\end{array}$ & Anticoagulation & 65 & None $(\mathrm{GOS})=5$ \\
\hline 11 & $\mathrm{M} / 34$ & Sm, Alcohol & Traumatic dissection & R-L- Right & $\begin{array}{l}\text { A: V3 Right } \\
\text { stenosis. }\end{array}$ & Anticoagulation & 6 & None $(\mathrm{GOS})=5$ \\
\hline 12 & $M / 29$ & Sm, Dyslip. & $\begin{array}{l}\text { Spontaneous } \\
\text { dissection }\end{array}$ & RC-L- Right & $\begin{array}{l}\text { A: V4 bilateral } \\
\text { stenosis. }\end{array}$ & Aspirin & 7 & None $(\mathrm{GOS})=5$ \\
\hline 13 & $\mathrm{~F} / 48$ & $\begin{array}{l}\text { Estenosis } \\
\text { mitral, } \\
\text { Dyslip. }\end{array}$ & Cardioembolic & C-L- Right & $\begin{array}{l}\text { A: V3-4 Right } \\
\text { occlusion. }\end{array}$ & Clopidogrel & 12 & $\begin{array}{l}\text { Severe dysphagia } \\
(\mathrm{GOS})=3\end{array}$ \\
\hline 14 & $M / 52$ & $\mathrm{AH}, \mathrm{PFO}$ & Cardioembolic & C-L- Right & $\begin{array}{l}\text { A: PICA } \\
\text { stenosis }\end{array}$ & Aspirin & 3 & No $(G O S)=5$ \\
\hline 15 & $\mathrm{~F} / 37$ & PFO & Cardioembolic & C-L- Left & $\begin{array}{l}\text { A: PICA distal } \\
\text { occlussion }\end{array}$ & Clopidogrel & 8 & Vrtigo $(\mathrm{GOS})=4$ \\
\hline 16 & $M / 33$ & $\begin{array}{l}\text { PF0, Dyslip, } \\
\text { ISA, FVL, } \\
\text { AFL, SLE. }\end{array}$ & Cardioembolic & R-L- Left & A: normal & Anticoagulation & 17 & $\begin{array}{l}\text { Dysarthria, } \\
\text { dysmetria, } \\
\text { nystagmus (GOS) = } 4\end{array}$ \\
\hline 17 & $\mathrm{M} / 60$ & $\begin{array}{l}\text { Alcohol, } \\
\text { Dyslip, DM. }\end{array}$ & Cardioembolic & C-L- Right & $\begin{array}{l}\text { A: PICA } \\
\text { occlusion }\end{array}$ & Ticlopidine & 13 & No $(G O S)=5$ \\
\hline 18 & $\mathrm{M} / 60$ & $\begin{array}{l}\text { AH, Alcohol, } \\
\text { Sm., Dyslip. }\end{array}$ & Cardioembolic & C-L- Left & $\begin{array}{l}\text { A-RMI: V4 Left } \\
\text { stenosis. }\end{array}$ & Aspirin & 2 & No $(G O S)=5$ \\
\hline 19 & $\mathrm{M} / 63$ & $\begin{array}{l}\text { AH, Alcohol, } \\
\text { DM, Dyslip. }\end{array}$ & Cardioembolic & C-L- Left & $\begin{array}{l}\text { A: V4 Left } \\
\text { stenosis. }\end{array}$ & Ticlopidine & 36 & No $(G O S)=5$ \\
\hline 20 & $\mathrm{~F} / 47$ & $\mathrm{AH}$ & Atherothrombotic & C-L- Right & $\begin{array}{l}\text { A: V4 Right } \\
\text { stenosis. }\end{array}$ & Clopidogrel & 12 & No $(G O S)=5$ \\
\hline 21 & $\mathrm{~F} / 49$ & $\begin{array}{l}\text { Ah, Sm., } \\
\text { Dyslip. }\end{array}$ & Atherothrombotic & C-L- Right & $\begin{array}{l}\text { A: V4 Right } \\
\text { stenosis. PICA } \\
\text { stenosis }\end{array}$ & Aspirin & 2 & $\begin{array}{l}\text { Dysarthria, facial } \\
\text { hypoesthesia } \\
\text { (GOS) }=4\end{array}$ \\
\hline
\end{tabular}


Table 1. General characteristics of patients with Wallenberg syndrome and isolated medullary infarction (WS-IBLI) $\mathrm{n}=26$ (Continued)

\begin{tabular}{|l|l|l|l|l|l|l|l|l|}
\hline $\mathbf{N}$ & S/A & Risk factors & Etiology & $\begin{array}{l}\text { Topography } \\
\text { (MRI) }\end{array}$ & $\begin{array}{l}\text { Arterial } \\
\text { findings }\end{array}$ & Treatment & $\begin{array}{l}\text { Follow- } \\
\text { up (M) }\end{array}$ & Sequelae (GOS) \\
\hline 22 & M/68 & $\begin{array}{l}\text { Previous } \\
\text { Stroke, AH }\end{array}$ & $\begin{array}{l}\text { Atherothromboembolic } \\
\text { A-A }\end{array}$ & C-L- Left & $\begin{array}{l}\text { D, MRI: V1 Left } \\
\text { stenosis. }\end{array}$ & Aspirin & 6 & Vertigo (GOS) =4 \\
\hline 23 & F/77 & $\begin{array}{l}\text { Previous } \\
\text { Stroke, AH, } \\
\text { DM }\end{array}$ & Cryptogenic & R-C-L & ---- & Aspirin & 0 & Death (GOS) =1 \\
\hline 24 & F/77 & AH & Cryptogenic & R-L- Right & ---- & Aspirin & 36 & Dysphonia (GOS) $=4$ \\
\hline 25 & F/37 & Sm, Alcohol & Cryptogenic & C-L- Right & A: normal & Aspirin & 2 & No (GOS) $=5$ \\
\hline 26 & M/19 & ---- & Cryptogenic & C-L- Right & A: normal & Aspirin & 15 & No (GOS) =5 \\
\hline
\end{tabular}

PFO: patent foramen ovale; ISA: interatrial septum aneurysm; PCD: protein C deficiency; APL: antiphospholipid; SAPL: secondary antiphospholipid; C-L: caudal-lateral; R-L: rostral-lateral; RC-PL: rostral-caudal-postero-lateral; CP-L: caudal-postero-lateral; A: angiography; A-MRI: angio-magnetic resonance; D: Doppler neck/transcranial; Sm: smoking; AH: arterial hypertension; DM: diabetes mellitus; Dyslip: dyslipidemia; SLE: systemic lupus erythematosus lupus; PICA: posteroinferior cerebellar artery;

S: sex; A: age (years); M: months; MRI: magnetic resonance imaging; CT: computerized tomography; A-A: arterio-arterial; FVL: Leiden V factor.

Table 2. Clinical manifestations, etiology, and prognosis of Wallenberg syndrome with isolated medullary infarction (WS-IBLI), $\mathrm{n}=26$

\begin{tabular}{|c|c|c|c|c|c|}
\hline Symptoms & & Signs & & Etiology & $n=26$ \\
\hline Vertigo/dizziness, n (\%) & $24(92)$ & Body hypoesthesia $n(\%)$ & $25(96)$ & Arterial dissection, $\mathrm{n}(\%)$ & $12(46)$ \\
\hline Gait ataxia, n (\%) & $20(77)$ & Nystagmus, n (\%) & $21(81)$ & Atherothrombotic, n (\%) & $8(31)$ \\
\hline Headache, n (\%) & $19(73)$ & Palate weakness, n (\%) & $21(81)$ & Cardioembolism, n (\%) & $4(15)$ \\
\hline Dysphagia, n (\%) & $17(65)$ & Horner, n (\%) & $19(73)$ & Cryptogenic, n (\%) & $2(8)$ \\
\hline Body hypoesthesia, n (\%) & $16(62)$ & Gait Ataxia, n (\%) & $19(73)$ & 30-days prognosis (GOS) & $n=26$ \\
\hline Vomiting, n (\%) & $15(58)$ & Facial hypoesthesia, n (\%) & $19(73)$ & (GOS 5) Good outcome, n (\%) & $16(61)$ \\
\hline Facial hypoesthesia, n (\%) & $15(58)$ & Nauseous abolished, $\mathrm{n}(\%)$ & $17(65)$ & (GOS 4), n (\%) & $8(30)$ \\
\hline Nausea, n (\%) & $15(58)$ & Dismetry, n (\%) & $14(54)$ & (GOS 3), n (\%) & $1(4)^{*}$ \\
\hline Horner, n (\%) & $14(54)$ & Facial paralysis, $n(\%)$ & $11(42)$ & (GOS 2), n (\%) & ------ \\
\hline Diplopia, n (\%) & $12(46)$ & Corneal reflex loss, n (\%) & $7(27)$ & (GOS 1) Death, n (\%) & $1(4)$ \\
\hline Dysmetry, (\%) & $11(42)$ & ------ & & $\begin{array}{l}\text { Functional prognosis ( } 17 \\
\text { months average) }\end{array}$ & $n=25$ \\
\hline Dysphonia or hoarseness, $\mathrm{n}(\%)$ & $11(42)$ & ----- & & (GOS 5) Good outcome, n (\%) & $24(96)$ \\
\hline Dysarthria, n (\%) & $11(42)$ & ----- & & (GOS 4), n (\%) & ------ \\
\hline Weakness, n (\%) & $9(35)$ & ----- & & (GOS 3), n (\%) & $1(4) *$ \\
\hline Hiccups or singultus, $n(\%)$ & $8(31)$ & ----- & & (GOS 2), n (\%) & ---- \\
\hline Facial paralysis, n (\%) & $6(23)$ & ----- & & (GOS 1) Death, n (\%) & ---- \\
\hline
\end{tabular}

*Dysphagia, GOS: Glasgow Outcome Scale.

\section{Discussion}

From the original clinical description made by Alex Marcet more than two centuries ago, and the first clinicopathological characterization made by Adolph Wallenberg at the beginning of the last century, WS syndrome is one of the most studied disorders throughout the history of neurology $4,6,13$. 
In our setting, WS has been analyzed on more than one occasion, with isolated clinical-radiological reports ${ }^{14-17}$. Despite this, there is no precedent for a relatively large cohort of patients with SW and IBLA that provides the clinical, radiological, etiological, and prognostic information as in the present study.

In our cohort, the patients with WS-IBLI were mostly men (2:1 ratio), similar to other reported series ${ }^{18-23}$. The average age of our patients was 45 years, a much lower average compared with the previous by other authors (55 years) $^{18-23}$. This may be due to the selection bias inherent in our reference hospital centers.

Traditional risk factors, including high blood pressure, diabetes, and dyslipidemia, were observed less frequently, due to the lower average age in our cohort. This observation is also supported by a higher frequency of alcoholism and smoking, more frequent in young patients ${ }^{24}$.

The caudal location of the ILMI predominated over the rostral topography in a 4:1 relationship. This finding is repeatedly reported by other series and is probably associated with the higher frequency of proximal vertebral artery involvement (due to stenosis or occlusion) observed in our study 9,11 .

Regarding the symptoms and signs of WS-ILMI, our patients did not show substantial differences with other reports $^{19,20,23}$. The most common symptom was vertigo in comparison with others studies reporting dysphonia and dyshagia as the main clinical findings ${ }^{25}$. Headache was observed in $73 \%$ of cases with no difference regarding age, sex, or infarct location. This frequency is higher than other WS series, where it is reported in $30-52 \%$ of patients ${ }^{19,23,26}$. A plausible explanation is the association of arterial dissection with a presenting headache.

However, in the signs and symptoms analysis of symptoms according to the location (not shown in tables), the group of patients younger than 45 years presented more significant gait ataxia $(p=0.01)$; while dysarthria, dysphagia, and peripheral facial paralysis were observed more frequently in the WS-IBLI of rostral location (all with $p<0.05$ ). This difference can be explained by the presence or absence of involvement of the ambiguous nucleus ${ }^{5,7}$. In rostral infarcts, this nucleus is affected, since these are narrower lesions that tend to affect the most ventral portion of the medulla ${ }^{7}$. Although the existence of facial paralysis is rare and its origin is unclear, in our series, this deficit occurred in a third of patients. It has been postulated that, in patients with facial paralysis, the injury could also affect the pons ${ }^{27}$. However, none of our patients had apparent involvement at this level. Kim, observed a greater involvement of the facial nerve fascicles and the corticobulbar fibers in relation to facial paralysis in rostral bulbar infarcts ${ }^{9}$.

In our cohort, the most frequent cause of WS-IBLI was arterial dissection (in < 45 years-old patients), unlike other series where it is reported as the second or third cause in frequency ${ }^{28,29}$. Vertebral dissection has also been reported as one the most common etiologies in young patients in some series ${ }^{30,31}$. Large vessel disease (atherothrombotic or atherothromboembolic) was the second cause associated with an age $>45$ years. A probable explanation for the higher incidence of arterial dissections in young patients is the higher frequency of high-risk physical and occupational activity (violent or abrupt) compared to older age groups. Of the infrequent causes, two cases with prothrombotic status were found as associated conditions: one patient with systemic erythematosus lupus (with positive antiphospholipid antibodies and factor V Leiden deficiency) and one with Protein $C$ deficiency, which is an uncommon association in the literature ${ }^{32,33}$.

The vascular abnormalities in our series coincide with those reported in the literature: vertebral artery stenosis was the most frequent, followed by vertebral artery occlusion, in $44 \%$ and $21 \%$, respectively. Only two patients had PICA involvement ${ }^{34,35}$.

Regarding complications, prognosis, and sequelae, our data are similar to that provided by the literature. WS usually has a benign prognosis with a low percentage of moderate and severe long-term complications and a 5 -year survival $>50 \%{ }^{36}$. Since our long-term follow-up was heterogeneous (range from 1 to 72 months), we were unable to perform a 5-year survival statistical analysis.

Most of the symptoms and signs of WS tend to improve rapidly, as occurred in our work. In contrast to other series, the most frequent sequela was sensory (cross-body paresthesia) followed by residual Horner syndrome; the only severe sequel was dysphagia ${ }^{37-39}$. In our series, only one patient died suddenly due to probable bronchoaspiration. Respiratory failure is usually the most common cause of death reported in WS ${ }^{39}$.

During follow-up, $61 \%$ of the patients had good recovery (GOS of 5 ) at 30 days and $96 \%$ in the long-term, confirming the benign prognosis of this syndrome.

\section{Conclusion}

Our study contributes to the clinical characterization of WS with a strictly lateral and isolated location 
(WS-IBLI), in addition to offering a new perspective on the functional prognosis in the medium term. A non-atherothrombotic etiology of SW should be considered in young patients with no other associated risk factors. Close monitoring and antithrombotic or anticoagulant therapy are essential in patients with SW to prevent stroke recurrence and to detect complications associated with this syndrome, which usually presents a benign course. The main limitation of this study was the selective sample of cases obtained from high concentrations centers which can lead to information biases. Further multi-center studies are needed in the future to complement the information presented in this manuscript.

\section{Funding}

This research has not received any specific grant from agencies in the public, commercial, or non-profit sectors.

\section{Con『icts of interest}

None to report.

\section{Ethical disclosures}

Protection of human and animal subjects. The authors declare that no experiments were performed on humans or animals for this study.

Con $\nabla$ dentiality of data. The authors declare that they have followed the protocols of their work center on the publication of patient data.

Right to privacy and informed consent. The authors declare that no patient data appear in this article.

\section{References}

1. Savitz S, Caplan LR. Vertebrobasilar disease. N Engl J Med. 2005;352:2618-26.

2. Tatu L, Moulin T, Bogousslavsky J, Duvernoy H. Arterial territories of human brain: brainstem and cerebellum. Neurology. 1996;47: 1125-35.

3. Caplan LR. Vertebrobasilar territory ischemia: an overview. In: Posterior Circulation Disease: clinical Findings, Diagnosis, and Management. Cambridge, England: Blackwell Science Ltd.; 1996. p. 179-97.

4. History of a singular nervous or paralytic affection, attended with anomalous morbid sensations. Med Chir Trans. 1811;2:217-35.

5. Wallenberg A. Acute bulbar affection. Arch Psychiatry Nervenheilkd $1895 ; 27: 504-40$

6. Wallenberg A. Anatomischer Befund in einem als Acute Bulbäraffection (Embolie der art. Cerebellar. Post. Inf. sinistr.). Beschriebenem falle. Arch Fr Psychiatr. 1901;34:923.

7. Currier RD, Giles CL, DeJong RN. Some comments on Wallenberg's lateral medullary syndrome. Neurology. 1961;11:778-91.

8. Roig C, Barraquer-Bordas LL. Historia del síndrome de Wallenberg. Rev Neurol (Barc). 1996;24:96-100.

9. Kim S. Pure lateral medullary infarction: clinical and radiological correlation of 130 acute, consecutive patient. Brain. 2003;8:1864-72.

10. Norrving B, Cronqvist $S$. Lateral medullary infarction: prognosis in an unselected series. Neurology. 1991;41:244-8.
11. Fukuoka $T$, Takeda $H$, Dembo $T$, Nagoya $H$, Kato $Y$, Deguchi $I$, et al. Clinical review of 37 patients with medullary infarction. J Stroke Cerebrovasc Dis. 2012;7:594-9.

12. Jennett $B$, Bond $M$. Assessment of outcome after severe brain damage. Lancet. 1975;1:480-4.

13. Escobar-Izquierdo A. Nota biográfica de Adolf Wallenberg. Rev Mex Neuroci. 2007;8:296-8.

14. Roldán-Valadez E, Juárez-Jiménez $H$, Corona-Cedilloa R, Martínez-López M. Síndrome de Wallenberg: hallazgos en resonancia magnética con correlación clínica. Gac Méd Méx. 2007;143:420-32.

15. Estañol B, Juárez H, Díaz-Zambrano S, Boada FV, Ramos GG. Horizontal appendicular dysmetria in four patients with a typical Wallenberg's síndrome. Rev Invest Clin. 2000;52:415-7.

16. Estañol B, Lopez-Rios G. Neuro-otology of the lateral medullary infarct syndrome. Arch Neurol. 1982;39:176-9.

17. Castillo AL, Barahona-Garrido J, Criales S, Chang-Menéndez S, Torre A. Wallenberg's syndrome: an unusual case of dysphagia. Case Rep Gastroenterol. 2007;1:135-43.

18. Kitis O, Calli C, Yunten N, Kocaman A, Sirin H. Wallenberg's lateral medullary syndrome: diffusion-weighted imaging findings. Acta Radiol. 2004:45:78-84.

19. Kim J. Pure lateral medullary infarction: clinical-radiological correlation of 130 acute, consecutive patients. Brain. 2003;126:1864-72.

20. Cnyrim C, Rettinger N, Mansmann U, Brandt T, Strupp M, Central compensation of deviated subjective visual vertical in Wallenberg's síndrome. J Neurol Neurosurg Psychiatry. 2007;78:527-8.

21. Lee MJ, Park YG, Kim SJ, Lee JJ, Bang OY, Kim JS. Characteristics of stroke mechanisms in patients with medullary infarction. Eur $\mathrm{J}$ Neurol. 2012;19:1433-9.

22. Oshima F, Yokozeki M, Hamanaka M, Imai K, Makino M, Kimura M, et al. Prediction of dysphagia severity: an investigation of the dysphagia patterns in patients with lateral medullary infarction. Intern Med. 2013;52:1325-31.

23. Kameda W, Kawanami T, Kurita K, Daimon M, Kayama T, Hosoya T, et al. Lateral and medial medullary infarction a comparative analysis of 214 patients. Stroke. 2004;35:694-9.

24. Encuesta Nacional de Salud y Nutrición. Insituto Nacional de Salud Publica, Secretaria de Salud; 2012. Available from: https://www.ensanut. insp.mx/encuestas/ensanut2012/doctos/informes/ENSANUT2012ResultadosNacionales.pdf

25. Rigueiro-Veloso MT, Pego-Reigosa R, Brañas-Fernández F, Martínez-Vázquez F, Cortés-Laíño JA. Síndrome de Wallenberg: revisión de 25 casos. [Wallenberg syndrome: a review of 25 cases]. Rev Neurol. 1997;25:1561-4

26. Ogawa K, Suzuki Y, Oishi M, Kamei S. Clinical study of 46 patients with lateral medullary infarction. J Stroke Cerebrovasc Dis. 2015;24:1065-74.

27. Fisher CM, Tapia J. Lateral Medullary infarction extending to the lower pons. J Neurol Neurosurg Psychiatry. 1997;50:620-4.

28. Sacco RL, Fredo LF, Bello JA, Odel JG, Onesti ST, Mohr JP. Wallenberg's lateral medullary syndrome: clinical-magnetic resonance imaging correlations. Arch Neurol. 1993;50:609-14.

29. Mokri B, Wayne HO, Sandok BA. Spontaneous dissection of the vertebral arteries. Neurology 1988; 38: 880-5.

30. Inamasu J, Nakae S, Kato Y, Hirose Y. Clinical characteristics of cerebellar infarction due to arterial dissection. Asian J Neurosurg. 2018;13:9951000.

31. Park MG, Choi JH, Yang TI, Oh SJ, Baik SK, Park KP. Spontaneous isolated posterior inferior cerebellar artery dissection: rare but underdiagnosed cause of ischemic stroke. J Stroke Cerebrovasc Dis. 2014;23: 1865-70.

32. Shimomura T, Takahashi S, Tamura K, Nozaki A, Akiho N. A case of Wallenberg's syndrome with systemic lupus erythematosus and antiphospholipid syndrome. Nihon Naika Gakkai Zasshi. 1993;82:588-9.

33. Stutzer G. Lupus erythematodes acutus with Wallenberg's syndrome. Z Haut Geschlechtskr. 1967;42:329-34.

34. Kim JS, Lee JH, Choi CG. Patterns of lateral medullary infarction: vascular lesion-magnetic resonance imaging correlation of 34 cases. Stroke. 1998;29:645-52.

35. Vuilleumier P, Bogousslavsky J, Regli F. Infarction of the lower brainstem. Clinical, etiological and MRI-topographical correlations. Brain. 1995;118:1013-25.

36. Caplan LR, Pessin MS, Scott RM. Poor outcome after lateral medullary infarctions. Neurology. 1986;36:1510-3.

37. Rigueiro-Veloso MT, Pego-Reigosa R, Brañas-Fernández F, Martínez-Vázquez F, Cortés-Laíño JA. Síndrome de Wallenberg: revisión de 25 casos. Rev Neurol. 1997;25:1561-4.

38. Kim JS, Choi-Kwon S. Sensory sequelae of medullary infarction: differences between lateral and medial medullary syndrome. Stroke. 1999;30:2697-703.

39. Bogousslavsky J, Khurana R, Deruaz JP, Hornung JP, Regli F, Janzer R, et al. Respiratory failure and unilateral caudal brainstem infarction. Ann Neurol. 1990;28:668-73. 